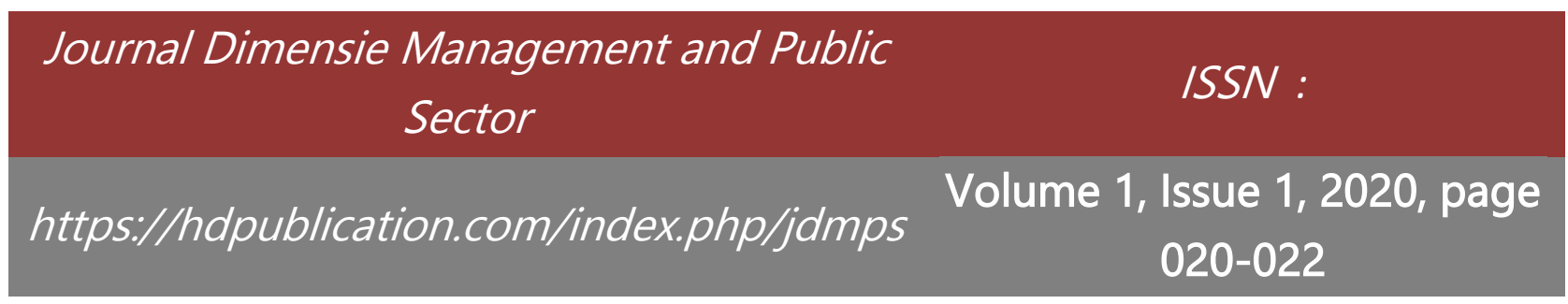

\title{
Developments in the Informal and Formal Sector
}

Simone Mingas ${ }^{1}$, Nguenha Bastos ${ }^{1}$

${ }^{1}$ Department of Economy, University of Eduardo Mondlane, Mozambique

*Corresponding Author: Simone Mingas

Received: October 28, 2020

Revised: November 12, 2020

Accepted: November 18, 2020

Abstract

The aims of the study to understand developments in the Informal and Formal Sector. This study discusses about the development of the informal and formal sectors a theoretical review of the informal and formal sectors, the concept of the informal sector the development of the informal and formal sectors. The informal and formal sectors have been running with their respective growth. The informal sector is a buffer against the transformation of unbalanced labor structures. Included as external factors are: First, that the institutions that support modern formal economic activities. Second, the wage level gap. Discrimination in the level of wages, both by informal institutions, the bureaucracy and the environment of formal economic actors themselves also perpetuates the separation of the two sectors. Third, related to technical-political issues, where political actors do not pay attention to and understand the rapid development of modernization.

Keywords: Formal Sectors, Informal Sector, Development

\section{Introduction}

The problem of the informal sector actually becomes increasingly important, but its condition is very important. Its existence is very important, especially after the economy is afflicted by a crisis like this, where the demand for the informal sector workforce is getting bigger along with the formal sector business cycle that is not running normally. The current economic condition has resulted in the formal sector being stingy in determining the supply of labor. There is even a big chance of laying off their workers, so that the informal sector is their foundation and hope in the future.

Janta et al. (2011) argues that The attitude of the formal sector, which is stingy in the absorption of labor, has a positive impact on the informal sector. How not, it is the informal sector that is expected to become a sector that can absorb a large number of unemployed people. Seeing symptoms like this, the decision makers in the government should make this sector at the same time become a challenge in itself to reverse the direction of economic development from being oriented towards economic growth to economic equality. However, the two still go hand in hand.

\section{Developments in the Informal and Formal Sector}

Prominent informal sector activities usually occur in highly populated areas, where unemployment and disquised unemployment are the main problems (Nwaka, 2005). 
With a reality like this the labor overflow enters the informal sector, but is still seen as a temporary solution because in the informal sector itself there are very complex problems.

So far, the informal and formal sectors have been running with their respective growth. The informal sector is a buffer against the transformation of unbalanced labor structures. When it was realized that the informal sector was able to make a significant contribution, both in the absorption of labor and in its output capacity, the perspective on this sector began to change. The informal sector is no longer just a shelter, but also a complementary alternative to the formal sector

Meanwhile, the level of intensity of formal activities is highly dependent on government policies in neutralizing a more democratic and participatory economic system. Formal jobs that better guarantee their lives are becoming more difficult to reach. Without opening economic access to the wider community, the established system will block the entry of labor. Small opportunities and large numbers of workers force them to build their own jobs that continue to grow in uncertainty (Kalleberg, 2011).

\section{The Informal and Formal Sector}

There are two factors that cause economic dualism between the formal and informal sectors to emerge, namely the first is related to external factors and the second is internal sectors. (Alter, 2005).

Included as external factors are: First, that the institutions that support modern formal economic activities. Although it looks like a complementary unified system that needs each other, formal and informal institutions are disaggregated by one another. This subordinative and recessive position results in the informal sector having a very weak bargaining position, so that it does not provide wider opportunities and the prospects are less favorable. Second, the wage level gap. Discrimination in the level of wages, both by informal institutions, the bureaucracy and the environment of formal economic actors themselves also perpetuates the separation of the two sectors. Third, related to technical-political issues, where political actors do not pay attention to and understand the rapid development of modernization. This third factor is characterized by the production of decision-making at the central and local levels as well as the regulatory paradox that supports and destroys various informal sector activities.

\section{Informal Sector Concept}

Sethuraman, (1976). The concept of the informal sector, which was first introduced clearly divides economic activities that are formal and informal The term informal sector by Keith Hart in 1971 in his research on small business units in Ghana. Then Hart's terminology was used by a mission to Kenya organized by the ILO (International Labor Organization). The mission argues that the informal sector has provided low cost, labor intensive, competitive goods and services, and provides recommendations to the Kenyan government to encourage the informal sector.

The economy in the informal sector can be relatively more independent. Since growth in the formal sector directly improves the welfare of the economically weak groups, progress in the informal sector at the same time increases national income and improves income distribution (Loayza, 1999). If in the formal sector the lack of demand can cause an economic downturn, 
in the informal sector the demand will always be strong, because the goods and services are needed by society on a daily basis.

\section{Developments in the Informal and Formal Sector}

There are several Developments in the Informal and Formal Sector namely: (1) Agriculture, Forestry and Fisheries, (2) Mining and Quarrying (3) Processing Industry (4) Electricity, gas and water, (5) Buildings, (6) Wholesale, Retail, Restaurants and Hotels, (7) Transportation / Transportation, Warehousing. And Communication (Addomah-Gyabaah, 2009)

\section{CONCLUSION}

The informal and formal sectors run with their respective growth. The informal sector is a buffer against the transformation of unbalanced labor structures. When it was realized that the informal sector was able to make a significant contribution, both in the absorption of labor and in its output capacity, the perspective on this sector began to change. The informal sector is no longer just a shelter, but also a complementary alternative to the formal sector. The government and the bureaucracy are still having difficulty working on and developing the informal economy completely and are often hit by several obstacles: lack of descriptive or analytical knowledge about the type, unit and extent of this informal economy activity, the inability of the bureaucrat's power to reach rural areas, rural areas, and slum settlements, which are mostly occupied by informal actors, lack of personnel who are able to know well the ins and outs of the informal economy and ack of sources of funds to meet the demands of this vast traditional sector.

\section{References:}

Addomah-Gyabaah, 2009) K. The Measurement Of Informal Sector Services In The Ghanaian National Accounts. On The Informal Sector And Economic Policy In Sub-Saharan Africa.

Alter Chen, M. (2005). Rethinking the informal economy: Linkages with the formal economy and the formal regulatory environment (No. 2005/10). WIDER Research Paper.

Hart, K. (2006). Bureaucratic form and the informal economy. Linking the formal and informal economy: Concepts and policies, 21-35.

Janta, H., Ladkin, A., Brown, L., \& Lugosi, P. (2011). Employment experiences of Polish migrant workers in the UK hospitality sector. Tourism Management, 32(5), 10061019.

Kalleberg, A. L. (2011). Good jobs, bad jobs: The rise of polarized and precarious employment systems in the United States, 1970s-2000s. Russell Sage Foundation.

Loayza, N. (1999). The economics of the informal sector: a simple model and some empirical evidence from Latin America. The World Bank.

Nwaka, G. I. (2005). The urban informal sector in Nigeria: towards economic development, environmental health, and social harmony. Global Urban Development Magazine, 1(1), 1-11.

Sethuraman, S. V. (1976). The urban informal sector: Concept, measurement and policy. Int'I Lab. Rev., 114, 69. 